ARTIGOS - ARTICLES

\title{
Leitores e leituras acadêmicas de Karl Marx (São Paulo, 1958-1964) ${ }^{1}$
}

\author{
Lidiane Soares Rodrigues \\ Professora Adjunta do Departamento de Ciências Sociais da Universidade Federal de São Carlos (UFSCar/SP) \\ lsr@ufscar.br
}

Recebido em 29/12/2015. Aprovado em 29/04/2016.

Como citar este artigo: Rodrigues, Lidiane Soares. "Leitores e leituras acadêmicas de Karl Marx (São Paulo, 19581964)”. Intelligere, Revista de História Intelectual, São Paulo, v. 2, n. 1 [2], p. 1-19. 2016. Disponível em

$<$ http://revistas.usp.br/revistaintelligere $>$. Acesso em dd/mm/aaaa.

Resumo: Ideias, livros e conceitos de Karl Marx e de diversos autores marxistas foram incorporados às instituições científicas e culturais. Trata-se de uma importação da esfera política para a acadêmica que implicou rotações de sentido em relação às suas origens e conferiu ao marxismo, por meio das práticas dos agentes desta transferência, suporte para sua conservação, difusão e transformação. Concomitantemente, desenvolve-se a incorporação destas linhagens às leituras obrigatórias das ciências humanas e ao repertório de camadas cultivadas. O exame das apropriações que as elites acadêmicas e cultivadas realizaram de Marx, situá-las (tal obra e tais elites), institucionalmente: eis o que o presente artigo realiza. Sustentando que a legitimidade dos usos de uma tradição resulte não exclusivamente de seu valor intrínseco, mas do trabalho orientado de agentes interessados nela, elege-se uma experiência exemplar para a investigação. Este artigo trata de dois grupos universitários voltados inicialmente ao estudo da obra de Karl Marx, constituídos no final dos anos 1950. Inicia-se apresentando uma biografia coletiva dos mesmos, o programa de leituras e os usos diversos que fizeram delas. Para afinar a análise e por à prova o método defendido, seleciona para exame vertical, no interior de um grupo (o primeiro deles) e de uma disciplina (a Sociologia), duas trajetórias contrastantes (Fernando Henrique Cardoso e Octavio Ianni) e modalidades diversas de marxismo (teórico e empírico / dominante e dominado). Finalmente, discute os ganhos propiciados por operar com três noções chave da sociologia da cultura no exame apresentado: habitus, campo e padrões de intenção - extraídos, respectivamente de Pierre Bourdieu e Michael Baxandall.

Palavras-chave: Marx no Brasil, Sociologia, Universidade, Trajetórias, Sociologia da Cultura e dos Intelectuais.

\section{Readers and academic reading of Karl Marx (São Paulo, 1958-1964)}

Abstract: Ideas, books and concepts of Karl Marx and various Marxist authors was incorporated into scientific and cultural institutions. It is one of the political sphere

${ }^{1}$ O que se apresenta resulta parcialmente de um período de estudos pós-doutoral, patrocinado pela FAPESP, junto à École des Hautes Études en Sciences Sociales (EHESS), em que fui acolhida por Afranio-Raul Garcia Jr., por intermédio de Sergio Miceli. Torno público meu agradecimento a ambos e à agência financiadora. 
importation into the academic implying sense of speed in relation to its origins and gave to Marxism, through the practices of the agents of this transfer, support for their preservation, dissemination and transformation. Concurrently, there is the incorporation of these lines to the required reading of the humanities and the repertoire of cultivated layers. Examination of appropriations that academic and cultured elites made of Marx, situate them (such work and such elites), institutionally. This is what this article does. Arguing that the legitimacy of the uses of a tradition result not only of their intrinsic value, but the work oriented agents interested in it, is elected an exemplary experience for research. This article looks at two university groups initially focused on the study of Karl Marx's work, made in the late 1950. It begins by proposing a collective biography, the reading program and the various uses they made of them. To refine the analysis and proof the advocated method selects for vertical take, within a group (the first one) and a discipline (sociology), two contrasting trajectories (Fernando Henrique Cardoso and Octavio Ianni) and various forms Marxism (theoretical and empirical / dominant and dominated). Finally, it discusses the profits propitiated to have operated with three concepts of cultural sociology: habitus, "field» and " patterns of intention » - taken from the works of Pierre Bourdieu and Michael Baxandall.

Keywords: Marx in Brazil, Sociology, University, Trajectories, Sociology of Culture and Intellectuals.

\section{Introdução}

As condições sociais e históricas que dão origem às teorias não são necessariamente as mesmas que propiciam sua longevidade. Se a obra de Karl Marx, e a tradição à qual as leituras dela deram início, por exemplo, tiveram emergência no campo político; lenta e paulatinamente, foram incorporadas às instituições científicas e culturais. Entrementes, a importação de um repertório teórico de uma esfera a outra - da política à científica - implicou rotações de sentido em relação às suas origens, encontrando nas práticas dos agentes desta transferência (alunos, professores, pesquisadores / teses, aulas, livros, comentários, seminários, congressos) suporte para sua conservação, difusão e transformação. Concomitantemente, processou-se a incorporação destas linhagens às leituras obrigatórias das ciências humanas e ao repertório de camadas cultivadas ${ }^{2}$. Tornou-se, hodiernamente, uma evidência que a perenidade da obra de Marx e da tradição marxista dependa de práticas distintas daquelas que lhe originaram $^{3}$. Valeria, ainda preliminarmente, assinalar que este processo, o qual Norbert Elias denominaria "intelectualização", não é exclusivo do marxismo, posto que algo similar ocorreu com a obra de Sigmund Freud e a psicanálise 4 .

O exame das apropriações que as elites acadêmicas e cultivadas realizaram de Marx, exige situá-las (tal obra e tais elites), institucionalmente. Esta orientação implica caracterizar o trabalho de legitimação deste e de outros autores, em determinadas disciplinas científicas, à luz de tradições intelectuais nacionais. Situados os agentes - isto é, identificados os princípios seletivos que eles imprimiram às leituras e os interesses específicos do campo científico que os motivaram - importa ainda identificar o conteúdo e os modos desta apropriação e incorporação: de um lado, livros, autores, conceitos, ideias, métodos; de outro, práticas de leitura, edição, citação, comentários. Não são numerosas as pesquisas que defendam esta abordagem dirigida ao exame do marxismo universitário. Apesar disso, destacam-se duas promissoras investigações.

2 Eric Hobsbawm, Como mudar o mundo (São Paulo: Companhia das Letras, 2011), 218.

3 A orientação filológica dada à reunião dos escritos de Karl Marx e Friedrich Engels (MEGA) é certamente o melhor exemplo atual disso. Ver.: Peter Schöttler, Jacques Grandjonc, "Une troisième MEGA? Entretien avec Jacques Grandjonc", Genèses (vol.) 11, n. 1 (1993): 137-147 ; Marcelo Musto, "La MEGA et les nouveaux visages de Karl Marx". La Pensée, 360, 2009.

${ }^{4}$ Norbert Elias, "Scientific establishments", em Scientific Establishments and Hierarquies, ed. Norbert Elias et. al. (Dordrecht: D. Rieder, 1982), 3-4. 
Isabelle Gouarné tratou da introdução do marxismo no campo científico francês, entre 1920 e 1939, por meio de um exame das instituições científicas, dos congressos internacionais, das trajetórias dos cientistas em circulação entre a Rússia e a França, neste intervalo de tempo. A autora chama atenção: a obra de Karl Marx e dos marxistas, por sólida e sofisticada que seja, não teria vigência entre os "científicos" não fosse o trabalho dos agentes de sua introdução, sedimentação e difusão. Este trabalho, por ela denominado de "invenção de um marxismo universitário", instituiu crivos seletivos oriundos do estado dos diversos domínios em que se realizou (psicologia, demografia, ciências sociais, filosofia). Se a obra de Marx na França remonta à vida do próprio autor, sua introdução, na sociologia, por exemplo, dependia do trabalho de operadores lógicos e sociológicos que o tornassem compatíveis com Durkheim 5 .

É preciso advertir: enganar-se-ia quem supusesse que esta proposta implica ignorar o marxismo partidário. Sendo o espaço dos leitores e das leituras organizado em torno dos campos político-partidário e do científico-pesquisa, é a relação entre ambos que precisa ser investigada, e, mais precisamente, qual a porosidade e a refração que o sistema partidário nacional e o sistema de ensino correspondente exercem um sobre o outro. O estudo realizado por Frédérique Matonti, a respeito do periódico Nouvelle Critique (1967-1980), é, nos limites deste levantamento bibliográfico, exemplar. Para analisá-lo, ocupou-se da relação dos agentes que o elaboravam, simultaneamente, com a direção do Partido Comunista Francês (PCF) e com os pólos dominante/dominado, de suas áreas de criação intelectual. Desse modo, delineou a coerção/liberdade negociada dos historiadores, sociólogos, lingüistas - em paralelo às atividades profissionais dos mesmos. E destronou interpretações que reduziam o PCF a uma espécie de "instituição total", controladora de "intelectuais domesticados". Contrariando esta visão, mostrou a fertilização conceitual suscitada por engenhosas alternativas criadas pelos intelectuais, que se submetiam parcial e refletidamente aos mandos da direção, posto que outros ganhos (como o gozo da participação política) faziam-nos acreditar valer a pena o custo de sua liberdade ${ }^{6}$.

O presente trabalho pretende unir seus esforços ao destas autoras.

Tendo em vista o amplo processo denominado acima por "intelectualização" do marxismo e esposando que a legitimidade dos usos de uma tradição resulte não exclusivamente de seu valor intrínseco, mas do trabalho orientado de agentes interessados nela, elege-se uma experiência exemplar para a investigação. Este artigo trata de dois grupos universitários voltados inicialmente ao estudo da obra de Karl Marx, constituídos no final dos anos 1950. Inicia-se apresentando uma biografia coletiva dos mesmos, o programa de leituras e os usos diversos que fizeram delas. Para afinar a análise e por à prova o método defendido, seleciona para exame vertical, no interior de um grupo (o primeiro deles) e de uma disciplina (a Sociologia), duas trajetórias contrastantes (Fernando Henrique Cardoso e Octavio Ianni) e modalidades diversas de marxismo (teórico e empírico / dominante e dominado). Finalmente, discute os ganhos propiciados por operar com três noções chave da sociologia da cultura: habitus, campo e padrões de intenção - extraídos, respectivamente de Pierre Bourdieu e Michael Baxandall.

\section{Sociogênese de uma prática: ler $O$ Capital com amigos, "filosoficamente"}

Em 1958, ao voltar de uma estada na França, o filósofo José Arthur Giannotti reuniu amigos, para ler O Capital, de Karl Marx. Além dele, frequentaram as reuniões deste grupo, com graus variados de assiduidade e envolvimento: os filósofos Bento Prado Jr. e Ruy Fausto,

\footnotetext{
5 Isabelle Gourarné, L'introduction du marxisme em France (Rennes : Presses Universitaires de Rennes, 2013), 182-190.

${ }^{6}$ Frédéric Matonti. Intellectuels communistes. Essai sur l'óbéissance politique. (Paris: La Découverte, 2005). Destacam-se estes dois trabalhos por se deterem especificamente na questão das esferas política e científica. Contudo, há outros que se aparentam a eles, no que tange à busca de alternativas a categorias de alcance heurístico reduzido, descritivas e normativas, como "marxismo de cátedra", "marxismo ocidental", "verdadeiro marxismo", "traição do marxismo", etc. Notadamente, o estudo da recepção de Marx na Argentina, realizado por Horacio Tarcus, Marx en la Argentina. Sus primeros lectores, obreros, intelectuales y cientificos (Buenos Aires: Siglo XXI, 2007).
} 
os sociólogos Fernando Henrique Cardoso e Octavio Ianni, o historiador Fernando Novais, o sociólogo e crítico literário Roberto Schwarz, os economistas Paul Singer, Sebastião Advíncula da Cunha e Juarez Rubens Brandão Lopes - entre outros, mais jovens do que eles, como Francisco Weffort. Esta iniciativa e os percursos destes seminaristas são indissociáveis da história da Faculdade de Filosofia, Ciências e Letras da Universidade de São Paulo (doravante, FFCL-USP) e da circulação num espaço internacional assimétrico de intercâmbio de práticas e ideias, realizada pelo mentor do grupo.

Fundada em 1934 e idealizada como alternativa às escolas tradicionais na formação das elites políticas, a FFCL-USP, seguiu rumos distintos dos que lhe foram atribuídos inicialmente. Sua consolidação institucional se processou numa "faixa crescente de desencontro entre os objetivos" do desiderato original, "tal como fora definido pelos setores de elite que eram seus mentores" ", e a direção profissionalizante que correspondia à atividade da clientela que efetivamente garantiria seu funcionamento. Nos primeiros anos da instituição, era marcante a presença de camadas sociais em descenso. Porém, crescentemente o estilo de trabalho ensaístico, associado à cultura letrada adquirida no berço familiar por esses grupos, destinados ao exercício do poder político, não mais se reproduz na escola. O recrutamento dela passa a se realizar entre extratos para as quais a novidade dos cursos é um atrativo e a incerteza do valor dos diplomas é, ainda assim, uma chance de ter uma profissão notadamente, mulheres e filhos de imigrantes ${ }^{8}$. Gradativamente, entra em vigência um estilo de trabalho intelectual menos diletante, associado à disposição para o trabalho ascético e que mobiliza competências adquiridas por via escolar.

O círculo em questão corresponderia a este perfil (plebeu e laborioso), salvo pelo fato de ser exclusivamente masculino (e, de início, contar com a frequência esporádica de membros da aristocracia em declínio, que o abandonará, avessa ao ascetismo que caracteriza esta roda). Aí se encontram procedentes de imigrantes: José Arthur Giannotti e Octavio Ianni são descendentes de famílias italianas estabelecidas no interior de São Paulo; Roberto Schwarz e Paul Singer, de famílias judias estabelecidas na capital. Fernando Novais era filho de professor primário que ascendeu a inspetor. Os brasileiros, Fernando Henrique e Bento Prado Jr., tinham origem em "elites empobrecidas, de famílias ligadas à burocracia estatal (civil e militar), ao magistério secundário e ao desempenho de encargos intelectuais e culturais". A heterogeneidade é o traço característico do grupo, em oposição a certa homogeneidade do recrutamento das antigas escolas, celeiros da burocracia estatal. Esta diversidade de origens consiste no fundamento de numerosas tomadas de posição e confrontos intelectuais. Em contrapartida, a leitura coletiva, regrada, constante e prolongada no tempo, intensificou laços prévios de amizade e promoveu o alinhamento das modalidades de excelência de trabalho intelectual compartilhadas pelos membros - operou, em suma, a homogeneização e inculcação de certo babitus ${ }^{10}$.

As reuniões ocorriam quinzenalmente, aos sábados à tarde, alternando as casas dos participantes em que se realizavam e os expositores do texto. A cada um cabia a apresentação de um excerto ao qual se sucedia uma discussão e um jantar. O seminarista devia "explicar" seu excerto, seguindo o método conhecido como "leitura estrutural do texto". A presença deste método de leitura deve-se ao trabalho das missões francesas contratadas para lecionarem durantes as primeiras décadas da FFCL-USP. Na Filosofia, seu estabelecimento se deveu principalmente à presença de Martial Guéroult, nos anos 1950, e posteriormente, ao fluxo contínuo dos alunos brasileiros recebido por Victor Goldschmidt na Universidade de Rennes de onde retornava Giannotti na ocasião em que organiza o grupo de estudos ${ }^{11}$. Grosso modo, o

${ }^{7}$ Sergio Miceli, "Condicionantes do desenvolvimento das ciências sociais" em História das ciências sociais no Brasil, v. 1, ed. Sergio Miceli (São Paulo: Sumaré, 2001), 105.

${ }^{8}$ Fernando Limongi, "Mentores e clientelas da Universidade de São Paulo", em História das ciências sociais no Brasil, v. 1, ed. Sergio Miceli (São Paulo: Sumaré, 2001).

9 Sergio Miceli. "Contra o retrocesso". Folha de S. Paulo, 11 de setembro de 1999.

${ }^{10}$ Não se dispõe de espaço para expor todos os liames de amizade prévia, importa apenas mencioná-los. Trabalha-se com a noção de campo e habitus tal como formulada por Pierre Bourdieu, As regras da arte. (Lisboa: Editorial Presença, 1996). Uma discussão da operacionalidade destas noções em afinidade com o que se procura neste trabalho encontra-se em Loïc Wacquant, "Esclarecer o habitus", Educação e linguagem, 16, 2007.

11 Uma explanação e uma justificação históricas da defesa do "tempo lógico" em detrimento do "tempo histórico", para a explicação dos sistemas filosóficos, foi proferida por Martial Guéroult, "Leçon 
método consistia em explicitar a construção lógica dos argumentos do autor, eliminando rigorosamente da explicação dela as condicionantes históricas (excerto 1). Ele era aplicado a autores clássicos, que viveram em tempos longínquos, cuja obra constituía um "sistema filosófico". Portanto, era algo de inédito no cenário adotar tal método para ler o texto de Karl Marx, implicando um problema. Seria ele apropriado para ler O Capital - livro tão incontornavelmente atrelado ao desenvolvimento histórico e de um autor tão dubitável em termos de encerramento de um sistema filosófico? Os seminaristas e o filósofo do grupo não ignoravam a questão. E se insistiram no método é porque sem ele a pedra de toque do empreendimento - tornar Karl Marx um autor legítimo academicamente (excerto 2) - não vingaria; e porque, no Brasil, ele ganhou sentidos diversos daquele originalmente formulado por Guéroult ${ }^{12}$.

A motivação do filósofo José Arthur Giannotti, mentor do grupo e zelador da execução desta metodologia de leitura, foi instada por sua circulação no espaço assimétrico das trocas internacionais de sua área ${ }^{13}$. Durante os dois anos em que estudou em Rennes e Paris, ele se familiarizou com práticas inéditas no cenário paulistano (leitura, comentário e tradução dos autores em que se especializavam os franceses e alemães) e com a hierarquia nacional e autoral do campo global filosófico (a França o acolhia, mas também ela sofria a dominação simbólica dos alemães nesse âmbito). Impactado, elaborou uma resposta ativa à dupla dominação (em relação à França e à Alemanha), e, relatando seus dramas a seu professor, João Cruz Costa, afirmou: "adotei uma divisa: estudar os alemães modernos à moda francesa. Vamos ver o que vai dar. Afinal o nosso barbudo era alemão (judeu) e ainda vamos lê-lo no original." 14

Há um liame entre a demanda por competências específicas instrumentais, (linguísticas e disciplinares) e a recomposição do grupo (saída de uns, entrada de outros). Embora a reconstituição factual desse processo seja impossível, a caracterização deste nexo é factível. A credibilidade do método de leitura dependia do conhecimento da língua original dos textos e a inteligibilidade do "sistema filosófico" em questão requeria o domínio dos clássicos da Economia Política. As margens entre estas demandas e o capital cultural dos jovens professores assistentes definem alguns convites que vai dando contorno ao grupo. Ora, qual o capital social dotado das competências em falta e à disposição do pequeno núcleo formado pelos professores-assistentes de catedráticos - posto não gozarem de ascendência cultivada em São Paulo - senão seus (ex)alunos brilhantes? Assim, Fernando Novais convida Paul Singer, seu ex-aluno na Faculdade de Ciências Econômicas e Administrativas (FCEA-USP). Por meio deles, também se unem ao grupo - Juarez Rubens Brandão Lopes e Sebastião Advíncula da Cunha. Estes três últimos têm sua formação deslocada no núcleo da FFCL-USP. São convidados tendo em vista as dificuldades de acompanhamento das discussões econômicas dos textos que o grupo se dispõe a ler ${ }^{15}$. Ademais, Singer não é convidado apenas por seu domínio da "ciência cinza". Ele e Schwarz, ex-aluno de Fernando Henrique Cardoso no curso de Ciências Sociais, filhos de imigrantes alemães, possuem o indispensável domínio da língua materna do autor a ser lido. Este recurso linguístico possibilitará realizar a leitura d'O Capital de modo coerente com o método de explicação filosófico (os demais seminaristas acompanharam em espanhol, francês e inglês). As competências instrumentais (língua e economia) são de domínio dos que terão uma posição dominada no início do grupo ao passo que o domínio do

inaugurale, Chaire d'histoire et technologie des systèmes philosophiques" (Paris: Collège de France, 1952). Na vida da instituição, este projeto circula por meio de um texto de Victor Goldschmidt, "Tempo histórico e tempo lógico na interpretação dos sistemas filosóficos" em $A$ religião de Platão. (São Paulo: Difel, 1963).

12 Esta adaptação esteve no centro da pesquisa de estágio pós-doutoral, antes mencionada. Dito de modo sumário: se Guéroult o justificava em função da posição assumida pela filosofia, junto à psicologia, ao ser importado para o Brasil, este método operou como uma espécie de cartilha educadora dos hábitos de leitura (impondo hierarquia dos textos e disciplina da prática), era "profilático", segundo Paulo Arantes, Um departamento francês de ultramar (São Paulo: Paz e Terra, 1994) - sentido, insistimos, adquirido na e pela importação do município paulistano.

13 Baseia-se, para este ponto em Johan Heilbron,"Exchanges culturels transnationaux et mondialisation: quelques réflexions", Regards sociologiques, 22, 2000 ; Gisèle Sapiro. "Le champ est-il national?", Actes de la Recherche en Sciences Sociales, 200, 2013.

14 José Arthur Giannotti, correspondência para João Cruz Costa (Paris, 28/10/1957).

15 Fernando Novais, Entrevista em Conversas com historiadores brasileiros, ed. José Marcio Rego. (São Paulo: Ed. 34, 2000), 96. 
"método de leitura" se concentra nos portadores da disciplina gradativamente dominante entre os leitores de Marx, a Filosofia (excerto 3). Entre um polo e outro, como se mostra adiante, o conteúdo temático da Sociologia vai se impondo.

Entre os seminaristas, vigorou a convergência de esforços coordenados voltados ao mesmo objetivo, mobilizando os recursos e competências que juntos reuniram: Giannotti é mentor do método de leitura, Roberto Schwarz possui domínio da língua alemã, pré-requisito para realização deste tipo de leitura, Paul Singer, além deste domínio, é convidado por ser economista. A virtual concorrência entre eles foi lentamente expulsa por meio da sedimentação de laços entre um representante de cada área. Assim, se Bento Prado Jr., Ruy Fausto e Giannotti - todos da Filosofia - concorrem no início das atividades, apenas o último permanece no posto de "superego teórico"; também não há outro crítico literário, a não ser Schwarz, nem outro historiador, a não ser Fernando Novais. Ainda que tenha levado outros economistas ao grupo, estes realizaram visitas esporádicas, e só Singer permaneceu vinculado. Se dois sociólogos, Fernando Henrique Cardoso e Octávio Ianni, compareciam no início, a troca recíproca de referências foi mais impactante para o primeiro, encorajado a se afirmar no pólo teórico da discussão de sua área. Como se mostra a seguir, ele representará a modalidade mais valorizada e legítima de prática entre marxistas (teoria), e o segundo, seu oposto (empiria).

O Capital não foi o único livro que leram juntos. Segundo eles, a publicação em francês de História e consciência de classe, de Georg Lukács, assim como de Questões de Método, de Jean-Paul Sartre, instou-os a parar a leitura de Marx para se dedicarem a estes dois livros. Novamente, é impossível a reconstituição do deslize da agenda de leituras, mas tudo leva a crer que a sugestão tenha partido dos mais jovens (excerto 3). Os seminaristas se reuniram entre 1958 e 1964, quando o estabelecimento da ditadura civil-militar levou Fernando Henrique Cardoso a sair do país. Entretanto, o encerramento das reuniões não implica o fim do grupo, dotado de uma extraordinária longevidade, condicionada por sua forma de organização do trabalho. Vale sublinhá-la: a inovação da forma de organização. Eles não foram os primeiros a lerem Marx na instituição, mas os primeiros a fazerem-no em grupo, com método filosófico, reunindo calculadamente capitais específicos para tanto e elegendo $O$ Capital como livro a ser lido. Os leitores isolados - lendo, cada qual a seu modo, um conjunto diferente de livros, destituídos de plataforma comum de problemas que os alinhasse e de recursos de difusão de sua prática - possuem uma capacidade mais baixa de promover efeitos no espaço institucional. Eis a divisa mais nítida em termos de inovação dos seminaristas - face tanto os leitores universitários de Marx que os antecederam quanto os solitários que os sucederam ${ }^{16}$. Esta inovação constituiu um diferencial e, não casualmente, os ingressantes no espaço passam a reproduzi-la.

O segundo círculo de leitura se formou em torno de dois membros que tiveram participação no seminário caracterizado acima. Em 1963, Roberto Schwarz retornava dos EUA e Ruy Fausto, da França. Eles reuniram colegas que, como eles, já tinham ido esporadicamente ao primeiro seminário - como Bento Prado Jr., Paul Singer, e os cientistas sociais Francisco Weffort, Michel Löwy e Gabriel Bolaffi. O segundo grupo contou também com a participação do filósofo João Quartim de Moraes e da filósofa Marilena Chauí; do arquiteto Sergio Ferro, da então estudante de medicina, Beth Milan, do economista Paulo Sandroni, da historiadora Emília Viotti, dos cientistas sociais Claudio Vouga, Emir Sader, José Francisco Quirino dos Santos, Lourdes Sola, Célia Quirino, Albertina Costa. A composição social dos membros deste grupo corresponde ao perfil tendencial de recrutamento dos alunos da FFCL-USP, tal como mencionado anteriormente. Roberto Schwarz, Ruy Fausto, Michael Löwy, Gabriel Bolaffi, Paul Singer têm origens judaicas, Emir Sader, libanesa. Além de imigrantes, diferentemente do grupo anterior, assinala-se presença feminina, equilibrando o número de estudantes por sexo.

As reuniões previam a "leitura de cerca de 50 páginas a cada duas semanas, valendose da diversidade de formação dos participantes num marco de homogeneidade geral em torno

\footnotetext{
16 A economia do artigo impõe que se restrinja esta apresentação ao conjunto de relações no interior do espaço acadêmico. Naturalmente, a pesquisa considerou o espaço de leitores político-partidários, a fim de surpreender as relações a que se fez referência introdutoriamente.
} 
do marxismo" 17. As reuniões não se encerraram após o golpe civil-militar, mas os propósitos do grupo vão se alterando e suas energias se voltam para a produção da revista Teoria e Prática. Esta publicação teve três números e foi interrompida devido à repressão policial em 1968. Ela consiste no suporte principal de publicização das atividades do grupo.

Excerto 1. "Os movimentos do pensamento filosófico estão inscritos na estrutura da obra (...) (isso implica) um tempo lógico (...) admitir um tempo lógico é bem menos formular uma teoria, por sua vez, dogmática, que uma regra de interpretação (...) (cujas diretrizes são) (...): 1. (ela) concerne à própria exegese dos métodos. Refazer, após o autor, os movimentos de que a estrutura da obra guarda o traçado, é repor em movimento a estrutura e, desse modo, situar-se num tempo lógico (...); 2. repor os sistemas num tempo lógico é compreender sua independência, relativa talvez, mas essencial, em relação aos outros tempos em que as pesquisas genéticas os encadeiam. A história dos fatos econômicos e políticos, a história das ciências, a história das ideias gerais (que são as de ninguém) fornecem um quadro cômodo, talvez indispensável, em todo o caso, não-filosófico, para a exposição das filosofias." 18

Excerto 2. "na falta de um escrito metodológico do próprio punho do autor, recorre-se geralmente a textos colhidos a esmo ao longo da leitura de suas obras. Mas o que se obtém é por demais fragmentário para explicar e esclarecer o sentido da produção científica do próprio Marx" (é preciso então) "extrairmos da própria obra efetuada os processos metodológicos que levaram à sua realização", e, por isso "minha intenção é subordinar o livro à mesma técnica de interpretação dos textos filosóficos (...) o livro de Marx exige a mesma conversão ao texto, que reclama toda obra filosófica de importância (...)" 19

Excerto 3. Ironia como reconhecimento da hierarquia; jovens/capital linguístico x professores/posição dominante da Filosofia. "Roberto começou sua brilhante carreira de falsário genial e fabricante de canulares de alto nível, inventando uma pretensa carta de Lukács dirigida a mim; nessa missiva, escrita num alemão impecável, o mestre de Budapeste agradecia o envio de artigos meus [Michael Löwy] e de Roberto, inspirados por sua obra, que mereciam grandes elogios, por sua excepcional qualidade intelectual e literária (estou citando de memória, não tenho mais esse precioso documento à mão). Cúmplice da manobra, levei a falsa mensagem de Lukács à seguinte reunião do Seminário Marx, onde ela foi lida e discutida, suscitando o ceticismo de alguns e a inveja de outros - não cito nomes". ${ }^{20}$

\section{Usos e efeitos inesperados de uma prática calculada}

São numerosas as diferenças entre os dois grupos e elas se expressam nas maneiras distintas de fazer uso das leituras coletivas. Esta seção estabelece um contraste entre a morfologia social de ambos, atrelando-a a estes usos, para tornar inteligível a concorrência cúmplice que objetivamente se processou entre eles ${ }^{21}$.

Do ponto de vista do perfil dos componentes, assinalou-se, há em “Teoria e Prática”, mulheres; ao passo que entre seminaristas, não. Neste, como se viu, o tipo de leitura proposta pressupunha uma aposta na autonomia do trabalho intelectual, tornando-o menos atraente

17 Emir Sader, "Nós que amávamos tanto o Capital” (Sociologias, 14, 2005), 172. As informações sobre o primeiro seminário são extraídas de Roberto Schwarz, "Um seminário de Marx" (Novos Estudos, 50, 1998).

18 Victor Goldschmidt, “Tempo lógico e tempo histórico...”, 142.

19 José Arthur Giannotti, "Notas para uma análise metodológica de O Capital', Revista Brasiliense, 29, 1960, 63.

20 Michael Löwy, "Ad Roberto" em Um crítico na periferia do capitalismo, ed. Milton Ohata (São Paulo: Companhia das Letras, 2007), 344.

21 Novamente, assinale-se que a análise completa caracterizaria a cumplicidade dos grupos (isto é, simultânea colaboração e concorrência), do ponto de vista: (a) da difusão de uma prática (ler em grupo); (b) da rotinização e crescente obrigatoriedade da leitura de Karl Marx; (c) do afastamento diferencial criado em relação aos não-leitores de Marx e aos leitores não-coletivos deste autor. Ela não é cabível no espaço disponível. 
para ativistas político-partidários. Com efeito, enquanto no Seminário, eles são ausentes; eles se reúnem no círculo "Teoria e Prática”. Estas duas características do Seminário - a ausência de mulheres / ausência de militantes - não são indiferentes uma à outra e tampouco ao feitio da produção do grupo. Ao contrário, realçam a feição scholar e profissional da leitura e do uso desta leitura pelos seminaristas - que fazem suas leituras renderem na elaboração e defesa de teses e na conquista de títulos. $\mathrm{O}$ propósito acadêmico explica tanto o fechamento às colegas/concorrentes/mulheres quanto a membros politizados e militantes partidários ${ }^{22}$. Por fim, a dimensão geracional, o índice da integração e respeitabilidade social distinguem os dois grupos. Os seminaristas são mais velhos, com famílias em vias de constituição, teses em andamento e obrigações assumidas junto aos catedráticos, por estarem em posições-chaves na hierarquia das suas disciplinas, dentro da instituição. Não dispõem de tempo para dividir os afazeres de docência, tese de doutorado e militância. Os seminaristas eram professores assistentes de catedráticos vitalícios e haviam feito toda sorte de trabalhos docentes necessários para o ganha-pão, porém mal remunerados e pouco prestigiados ${ }^{23}$. Entre esta posição compartilhada - senão instável, peculiarmente insatisfatória - e o modo em comum por meio do qual se apropriaram das leituras coletivas, isto é, importando-as para suas teses, há um liame, se apostarmos na investigação da correspondência entre disposições cognitivas e posições objetivas no espaço social ${ }^{24}$.

Os seminaristas não produziram artefato equivalente à revista do segundo grupo (doravante, "teórico-práticos") ${ }^{25}$. Suas discussões inacabadas deixaram rastros difusos e estão involuntariamente documentadas em suas teses - posto que fossem idealizadas como acabamento delas. As teses são, com efeito, o suporte mais expressivo dos "padrões de intenção" que um membro inculcou no outro durante anos a fio de convivência ${ }^{26}$. Para realizá-los, cada seminarista precisava articular o repertório compartilhado com os demais seminaristas e a agenda de pesquisa de sua disciplina. É por esta razão que as teses defendidas por eles são elaboradas e defendidas coletivamente. Evidentemente, há diversas maneiras de lê-las, e são numerosas as interpretações que já se fez do grupo e de seus trabalhos. Contudo, três parecem mais estratégicas para a recuperação objetiva dos "padrões de intenção": a. As teses umas em relação às outras; b. A relação das teses com a agenda da disciplina originária de cada seminarista; c. A relação das teses com (1) a Filosofia/ disciplina dominante no Seminário e com (2) a Sociologia/ disciplina dominante na FFCL-USP27.

A articulação destas três chaves de leitura permite restabelecer o diálogo interno ao grupo. É notável que, em função da natureza dispersa dos rastros-teses, parcela significativa da clientela dos seminaristas (pares/alunos - aliados/adversários), com o avançar dos anos, tenha passado a ignorar a coesão e perenidade dos vínculos entre eles. O prolongamento no tempo e a dispersão no espaço das disciplinas concorreram para esse processo contraditório de reposição da nota coletiva e esquecimento coletivo dela. No que se refira às teses que estabeleceram o mencionado diálogo: defenderam-nas, na Sociologia, em 1961, Fernando Henrique Cardoso e Octavio Ianni; em 1964, na Filosofia, José Arthur Giannotti; na História, em 1973, Fernando

22 O único membro do primeiro seminário com experiência em militância é Paul Singer. Os demais se envolvem na vida partidária décadas posteriores a esta experiência estudantil. Advirto, pois é corrente a inversão lógica e temporal destes nexos - indicador sociológico tangível da centralidade destas figuras, em fases distintas de sua trajetória, na estruturação disciplinar/científica e político/partidária do país.

23 Para destacar apenas exemplos concernentes a algumas figuras. José Arthur Giannotti tinha prestado concurso de Sociologia e lecionava a disciplina no interior do estado, antes de ir à França; Bento Prado Jr., em vias de contrair matrimonio, ia lecionar no Colégio de Aplicação, anexo à FFCL-USP; Fernando Novais trabalhava como assistente na FCEA-USP, na qualidade de professor licenciado de escola pública; Fernando Henrique Cardoso tinha trabalhado no colégio Fernão Dias.

${ }^{24}$ Pierre Bourdieu, La noblesse d'État (Paris: Les Editions de Minuit, 1989), 47.

25 Exceto um texto de José Arthur Giannotti, "Notas para uma análise metodológica de O Capital", (Revista Brasiliense, 29, 1960).

26 As teses eram uma "prova de fogo para o marxismo, porque a idéia era de fazer teses que além de marxistas fossem melhores do que as outras.", segundo Roberto Schwarz, "Entrevista" em Retrato de grupo, ed. Flavio Moura (São Paulo: Cosac, 2009). O que se propõe inspira-se em Michael Baxandall, Padrões de intenção (São Paulo: Companhia das Letras, 2006).

27 A posição dominante da Sociologia no espaço mais amplo das disciplinas foi caracterizada por Maria Arminda do Nascimento Arruda, "A Sociologia no Brasil: Florestan Fernandes e a 'escola paulista"' em História das Ciências Sociais no Brasil, v. 2, ed. Sergio Miceli (São Paulo: Sumaré, 1995); Sylvia Garcia, Destino Impar. (São Paulo: Editora 34, 2002). 
A. Novais; no exílio parisiense, em 1976, Roberto Schwarz defenderia a sua. A cada doutoramento e a publicação em livro destas teses, as referências teóricas, o repertório conceitual, as modalidades de excelência científica, o modo interpelar a agenda de sua própria disciplina e da Sociologia e a rotinização do método de leitura filosófico eram repostos face a uma clientela cambiante e cujos padrões de intenção, princípios de apreciação e julgamento marxistas ou não - eram diversos aos do grupo. A distância crescente entre estes produtores e esta clientela está na origem do número infindável de comentaristas das "obras" dos seminaristas que ignoram a experiência de inculcação de habitus do seminário, autor coletivo delas ${ }^{28}$.

Em contrapartida, poder-se-ia supor que a convergência em torno de uma publicação assinalasse vínculos mais estreitos do círculo "Teoria Prática". Nada mais enganoso. Considerando temas, autores de predileção, conjunto de citações coletivamente compartilhadas e obrigatórias, enfoques, disciplinas, idades dos membros, interesses, e graus de dedicação à vida intelectual, este grupo apresenta mais diversidade e mais dispersão. O artefato coletivo revista - unia em papel as divergências; ao passo que o artefato de autoria aparentemente individual - tese - disseminava um repertório convergente. Com efeito, a marca que os seminaristas lograram deixar nos trabalhos uns dos outros é indicadora da convergência dos seus esforços e dos laços estabelecidos. O contraste com o segundo círculo permite afirmar que a inculcação de um habitus que alinhou a diversidade (de sotaques do interior do estado com famílias migrantes, de diferenças de áreas, de disposições disciplinares incompatíveis) foi garantida, pela posição que ocupavam institucionalmente e as dificuldades a ela associadas, que estreitou a solidariedade de grupo. Dito de outro modo, a regularidade e longevidade das reuniões forjaram a homogeneidade a partir da diversidade geral das origens sociais dos componentes. Entrementes, a mesma configuração social poderia se fragmentar não fosse a âncora da dificuldade compartilhada, condicionando saídas comuns a ela: fazer valer o trabalho coletivo e o capital de leitura d'O Capital, legitimando Marx e os marxistas lidos, cada qual em sua área.

A despeito das diferenças assinaladas, a montagem de outro grupo, assumindo ou não abertamente a concorrência, retira dos seminaristas a exclusividade daquele atributo que haviam construído: o capital da leitura d'O Capital. E, no entanto, aumentando o número de praticantes da experiência, confere valor a ela ao autor/teoria no centro dela. Ora, a prática de ler em grupo era inédita no cenário da FFCL-USP e contrastava com leituras anteriores da obra de Karl Marx, realizadas individualmente. Do ângulo institucional, é possível pensar na capilaridade que a esta organização do trabalho propicia. Como os membros dos dois grupos tinham origens disciplinares diversas, o alcance desses seminários ultrapassa o espaço que privavam os círculos em questão. Aulas, publicações, congressos e toda sorte de práticas acadêmicas realizadas por cada membro foi marcada pela experiência. Se, pelas razões apresentadas acima, o primeiro grupo foi responsável pela legitimação autoral de Karl Marx na FFCL-USP, os dois trabalharam juntos pela rotinização da leitura desse autor. E nisso foram muito bem sucedidos. A fronteira entre seminaristas e teórico-práticos, dando-se no interior do valor acordado ao marxismo, cria social e simbolicamente outra fronteira: entre os que têm e os que não têm o capital desta leitura d'O Capital.

\section{Fernando Henrique Cardoso: “Macunaíma da Dialética”.}

A inteligibilidade dessa complexa interdependência intelectual e afetiva - em que os modos de pensar e sentir são instados pelos membros dos círculos de estudos uns em relação aos outros por meio da prática da leitura - pressupõe a investigação da colaboração interna ao grupo e da competição externa a ele. Entre os seminaristas, os contornos que gradativamente a configuração vai ganhando tende a favorecer a colaboração, posto que os membros não compitam preferencialmente entre si - por pertencerem a disciplinas diferentes. A tendência é que a prática atice a concorrência com os pares nas respectivas áreas, em duas direções: verticalmente, com seus catedráticos; horizontalmente, com seus colegas - ambas posições que foram destituídas de um capital específico - o de leitura d'O Capital, por meio do investimento

28 A limitação de espaço impõe que se parto do que já foi demonstrado em Lidiane Soares Rodrigues, $A$ produção social do marxismo em São Paulo (1958-1978). (Tese de doutorado, Universidade de São Paulo, 2012). 
dos seminaristas nesta prática. Contudo, a particularidade da Sociologia (dominante institucionalmente, e a mais competitiva das disciplinas), conferiu uma voltagem intensa a estes dois vetores potenciais da competição, somando a eles a concorrência entre os dois seminaristassociólogos: Fernando Henrique Cardoso e Octavio Ianni. A seguir, examina-se a concorrência que se processou na área de Sociologia, com vistas à direção vertical - entre "mestre" (o catedrático Florestan Fernandes) e "discípulo" (o primeiro assistente, Fernando Henrique Cardoso) - e à horizontal, entre ele e Octavio Ianni (o segundo assistente de Florestan Fernandes e igualmente seminarista de Giannotti).

No salão nobre da FFCL-USP, nos dias 12 e 13 de outubro de 1961, ocorreram as defesas dos doutoramentos dos sociólogos Fernando Henrique Cardoso e Octavio Ianni. As duas teses remontam à pesquisa realizada por Roger Bastide e Florestan Fernandes, nos quadros da encomenda da UNESCO, a respeito das relações raciais no Brasil, no qual seus alunos (agora assistentes) tinham tomado parte como iniciantes em pesquisa ${ }^{29}$. Em 1954, quando o primeiro retornou à França, deixando a cátedra de Sociologia I, sob a regência do segundo, este montou uma equipe de docentes e lhes atribuiu aulas e temas para suas respectivas teses. $\mathrm{Na}$ qualidade de primeiro e segundo assistentes de Florestan Fernandes, os sociólogos deveriam cumprir o plano de replicar a investigação a respeito das relações raciais numa área que não havia sido coberta pela referida pesquisa e que apresentava algumas particularidades em contraste com regiões mais estudadas (Excerto 4).

O que ocorreu entre o início do plano proposto por Florestan Fernandes e a conclusão dos doutoramentos destes alunos, para que se processasse neles uma ligeira rotação - do "tema das relações raciais para a ênfase entre escravismo e da formação do capitalismo"?30. Esse trânsito pode ser entendido à luz da necessidade de dialogar simultaneamente com o plano de pesquisa da Sociologia I (questão racial) e com o Seminário (relações escravistas e capitalismo) ${ }^{31}$. Cada seminarista formulou esta ambivalente embocadura: fazer dialogar a agenda de pesquisa de sua área com as referências teóricas, o método de leitura e os temas do Seminário. Evidentemente, sendo múltiplos os arranjos possíveis para solução desse problema, a elaboração dela foi realizada por eles sob três ordens de constrições indissociáveis e distintas, segundo as disciplinas: a história social prévia do seminarista, sua posição na hierarquia das cátedras e sua posição no "Seminário Marx". O entrelaçamento dessas três dimensões encontra-se na modalidade de defesa do marxismo que Fernando Henrique Cardoso e Octavio Ianni realizaram em suas teses, notadamente nas "Introduções" das mesmas.

A "Introdução" de tese de Fernando Henrique Cardoso foi pioneira no gênero das reflexões teóricas antepostas às teses, depois rotinizada na instituição. À época, um filósofo o informou que ela o tornara o "Macunaíma da dialética"32; anos depois, outro filósofo classificaria o texto como "o primeiro capítulo do marxismo ocidental uspiano"33. Ambíguas e irônicas, decerto; mas que o sociólogo suscitasse reações e atenções de filósofos não é algo irrelevante, indica sua orientação adotada no espaço disciplinar. Quanto à sociologia, o catedrático que dirigia o trabalho estava em desacordo com a justaposição da introdução, para além do conteúdo dela, e só cedeu, segundo conta seu aluno rebelde, depois que este "ameaçou" defender a tese junto à cadeira de Política ${ }^{34}$. Com efeito, o desafio estava feito na atitude e no conteúdo da referida introdução e era sustentado pela prática do grupo, pelo encorajamento mútuo, pela autoridade da batuta filosófica que participava tangencialmente do duelo, pois legislava a respeito de disciplinas científicas em geral, tal qual legislava a leitura do

29 O chamado "Projeto Unesco" consistiu num conjunto de pesquisas sobre relações raciais, realizadas entre 1951 e 1952, em vários estados brasileiros, patrocinadas pela Organização das Nações Unidas para a Educação, Ciência e Cultura (Unesco). Cf. O panorama nacional da pesquisa encontra-se em Marcos Chor Maio. A história do Projeto Unesco: Estudos Raciais e Ciências Sociais no Brasil (Tese de Doutorado, IUPERJ, 1997).

30 Maria Arminda do Nascimento Arruda, "A Sociologia no Brasil: Florestan Fernandes e a 'escola paulista"', 207.

${ }^{31}$ Este nexo está no centro dos temas de tese de todos os seminaristas, mas infelizmente não se dispõe de espaço para demonstrá-lo.

32 Bento Prado Jr., correspondência para Fernando Henrique Cardoso, Rennes, 02/12/1961.

33 Paulo Arantes, Um departamento francês de ultramar, 286.

${ }^{34}$ Fernando Henrique Cardoso, Entrevista em Conversas com sociólogos brasileiros, ed. José Marcio Rego et. al. (São Paulo: Editora 34, 2006). 
seminário.

Qual o conteúdo do texto, qual o nexo desta introdução com a tese e por que motivo Florestan Fernandes não o aprovou? Fernando Henrique Cardoso afirma que a "discussão" presente na "Introdução" é restrita à "caracterização do procedimento totalizador na interpretação dialética". Por esta razão, ele resumiria sua "análise à comparação desse procedimento com técnica diversa de interpretação, para salientar a peculiaridade dessa forma de conceber e explicar teoricamente a realidade social." 35

Entrementes, ao "comparar" e "salientar a peculiaridade" do procedimento totalizador da interpretação dialética, ele decretou a impotência das demais correntes sociológicas - estruturalismo e funcionalismo, notadamente - para fazer o mesmo ${ }^{36}$. Na referida introdução, Fernando Henrique Cardoso não discute o método dialético ${ }^{37}$. O jovem sociólogo defende a superioridade do mesmo na análise sociológica em detrimento das correntes estruturalistas e funcionalistas. Grosso modo, segundo a mencionada "introdução", on se é funcionalista, ou se é estruturalista, ou se é materialista dialético. A última escolha é melhor e superior porque explica o que as demais sequer vislumbram, a saber, explicação de processos diacrônicos (por meio da "totalidade", em sua versão lukaciana). Evidentemente, diante desta taxonomia, Florestan Fernandes - que já havia se ocupado das condições de possibilidade de uma sociologia em Marx, assim como dos temas e domínios sociológicos mais propícios para o uso de Marx, de Durkheim e de Weber - não é marxista ${ }^{38}$. Segundo seu pupilo, muito embora o mestre não seja conservador, ele é funcionalista ${ }^{39}$.

$\mathrm{O}$ ardil do argumento consiste em definir o atributo exclusivo do grupo a partir da propriedade de um atributo teórico que é exclusivo e excludente - só pertence ao seminário a autoridade do decreto a respeito do que é marxismo, resultado da prática socialmente conhecida e reconhecida. E com a "categoria de totalidade" (conforme o sentido emprestado a ela por Lukács), a marca distintiva do marxismo do grupo, confere-lhe superioridade, sendo possível construir intelectualmente um lugar menos nobre para o catedrático (institucionalmente superior) e mais poderoso para o seminário (institucionalmente inferior). A topografia do espaço hierárquico instando a competição das posições dominadas dirigidas às dominantes se sobrepõe à topografia do espaço teórico construído nesta introdução. E a proposta de inversão da hierarquia no plano teórico se explica pela evidência objetiva que constrange o artífice dela, submetido à dominação da mesma.

A tese seria defensável sem a "introdução" - e os indícios disso são dados pelo próprio sociólogo. Em primeiro lugar, a ardorosa defesa do conceito de totalidade, no que tange ao assunto da tese, justifica-se pela possibilidade de explicar a emergência da escravidão na fase de formação do capitalismo e sua supressão uma vez que este sistema alcançasse dinâmica própria. Entretanto, se esta explicação está no coração da justificativa para mobilizar

${ }^{35}$ Fernando Henrique Cardoso, Capitalismo e escravidão no Brasil meridional (São Paulo: Difel, 1962), 11 (os sublinhados são meus).

36 Resumo o exame detalhado dos expedientes discursivos mobilizados para este propósito realizado em Lidiane Soares Rodrigues, A produção social do marxismo em São Paulo, p. 231-252: são passadas a limpo as correntes funcionalistas e estruturalistas que também operam com a noção de "todo". Esta revisão é posta a serviço da defesa da superioridade explicativa da noção de totalidade, tal como formulada por Georg Lukács (1960) - que daria conta da complexidade histórica para a qual as demais correntes seriam inoperantes.

37 Como fizera anteriormente Florestan Fernandes, seja indicando os processos sociológicos que demandam a mobilização do marxismo, sejam as condições lógicas de articulação dele às demais teorias que compõem a Sociologia clássica - como demonstrou Maria Arminda do Nascimento Arruda, "A Sociologia no Brasil: Florestan Fernandes e a 'escola paulista"'.

38 Os exercício da jurisprudência da fronteira - quem é e quem não é marxista - obviamente, é intelectual e social. Sendo impossível recensear tudo que passa a ser realizado de modo impensado mas orquestrado, como resultado da inculcação do habitus, indico apenas que também outro seminarista dirige-se ao economista (já célebre e sem notícia do que fosse o seu seminário) Celso Furtado para afirmar: "embora o pretenda, sua concepção não é marxista". José Arthur Giannotti, "A propósito de uma incursão na dialética" (Revista Civilização Brasileira, 3, 1965), p. 108. Uma regra invariante dos grupos à esquerda, em suas disputas internas pela subversão consiste em remeter o adversário à posição menos radical, menos revolucionária, menos totalizante, como mostrou Eric Brun, Les situationnistes. (Paris: CNRS Éditions, 2014).

${ }^{39}$ Fernando Henrique Cardoso, Capitalismo e escravidão, 13. 
o método dialético, segundo reconhecimento do próprio sociólogo, ele não a alcança (Excerto 5). Em segundo lugar, é preciso considerar que o problema teórico que sustentou a pesquisa empírica (tanto documental quanto in loco) liga-se às insuficiências da pesquisa da UNESCO, a respeito das quais acordavam inicialmente. Não surpreende o contencioso com Florestan Fernandes. A pesquisa empírica que deu origem à tese iniciara-se em 1952, junto com Bastide, prolongava-se em 1955, junto com os assistentes enviados ao Sul para coleta de dados. Todo o esmero a propósito da articulação entre método, teoria e coleta empírica, a bem dizer, tinha sido em vão (novamente, excerto 4). Não era casual que a introdução pudesse interessar quem não estivesse interessado no tema da tese, assim como a tese poderia não ser lida por quem se interessasse pela introdução (Excerto 6). Tampouco que ela tivesse autonomia suficiente para ser publicada separadamente, como o foi, três vezes: no Brasil, na Argentina e no México ${ }^{40}$. Ela era postiça ao escopo da pesquisa, do ponto de vista da cadeira de Sociologia I. Por fim, se é verdade que o curso de uma pesquisa pode sofrer rotações, é de se supor que o deslocamento das relações raciais/presente em curso para as relações escravistas / capitalismo em formação exigisse procedimentos para os quais seriam necessários mais alguns anos de pesquisa empírica sob nova orientação teórica. Novamente, é da pena do próprio Fernando Henrique Cardoso que se recolhe a confissão. Depois de prestar contas quanto ao que "deixou de fazer" junto aos padrões de intenção do Seminário; presta contas junto padrões de intenção da Sociologia I (Excerto 7). De todo modo, em todas as edições em livro que a tese recebeu, a "introdução" foi mantida, e com o passar dos anos o autor procurou reafirmar posições junto ao marxismo ou ironizar sua própria atitude, adicionando novas apresentações ao texto ${ }^{41}$.

A "Introdução de Ianni” está dividida em duas partes - "temas" e "procedimentos". $\mathrm{Na}$ primeira parte, trata-se de apresentar a região geográfica, recuperar a justificativa do caso escolhido para o estudo, destacando a significação sociológica dos períodos de formação da sociedade escravista e desagregação da mesma. Também se apresenta a defesa do marxismo: "o tipo de exploração descritiva e interpretativa levada a efeito nesta obra, na medida em que depende do autor, é o resultado da aplicação do método dialético" ${ }^{42}$. Ianni também elege uma categoria analítica que legitima a escolha teórica, a saber: "estrutura econômico-social". Segundo ele, esta categoria possibilita "(evidenciar) perfeitamente os limites das determinações do social pelas configurações econômicas” (Idem, p. 21). Sem comparar, diferenciar e hierarquizar no contraste com outras linhagens que se valham da noção de estrutura, ele afirma: "a maioria (...) se não todas, são corretas ou (são) aceitáveis, pois elas exibem partes fundamentais do sistema social e indicam como se ligam e se influenciam" 43 . Seu "carro chefe conceitual", contudo, não é de "estrutura social", mas de estrutura sócio-econômica e com isso pretende assinalar "os fundamentos materiais de organização da vida social", motivo pelo qual a denomina "econômico-social" e não simplesmente 'social'." 44 . Não havendo aquela transferência invertida da topografia do espaço disciplinar para a topografia do espaço teórico, os trabalhos de Florestan Fernandes não são classificados, como no do seu colega de cadeira e pesquisa. O texto introdutório de Ianni trata de sua tese, é destituído do alarde das publicações em língua estrangeira e da celebração coletiva do seminário se reconhecendo no texto, e é suprimido da última edição da tese em livro, juntamente com a conclusão ${ }^{45}$. Se as supressões podem indicar um desprendimento com relação ao contexto de elaboração delas, também levam a indagar se seria mesmo o marxismo que sustentava a atenção aos processos

${ }^{40}$ Fernando Henrique Cardoso. "O método dialético na análise sociológica", Revista Brasileira de Ciências Sociais, II, 1962; "El método dialectico en el analisis sociológico” (México: ABIIS/UNAM, 1962); "El método dialectico en el analisis sociológico", Pasado y Presente, 7-8, 1965.

41 As publicações da introdução e as edições em livro a que se refere acima são: Fernando Henrique Cardoso. "Nota à $2^{\mathrm{a}}$ edição" em Capitalismo e escravidão no Brasil Meridional (Rio de Janeiro: Paz e Terra, 1997, 4 ed.); "Relendo papéis antigos" em Capitalismo e escravidão no Brasil meridional. (Rio de Janeiro: Civilização Brasileira, 2003), $5^{\mathrm{a}}$ ed.

42 Octavio Ianni. O negro na sociedade de castas. O regime servil numa comunidade do Brasil meridional. (Tese de doutoramento, FFCL-USP, 1961), 21.

${ }^{43}$ Idem, 22.

44 Idem, 26.

45 As publicações a que se refere são: As metamorfoses do escravo. (São Paulo: Difel, $1962-1^{\text {a }}$ ); As metamorfoses do escravo. São Paulo: Hucitec/'Scientia et Labor" (UFPR), 1988, $2^{\mathrm{a}}$ ed. revista e ampliada (sem introdução/conclusão originais). 
diacrônicos e à esfera econômica condicionando a ação dos agentes, como lhe tributava Ianni. A bem dizer, isso remonta a antigos textos do catedrático Florestan Fernandes ${ }^{46}$.

Como é evidente, se ambos, Fernando Henrique e Ianni, esforçaram-se para filiar suas teses ao materialismo histórico, não se valeram dos mesmos recursos para tanto. A divisa mais expressiva das modalidades opostas consiste no investimento em domínio teórico raro no mercado de competências da época, por parte de Fernando Henrique Cardoso; algo sem contrapartida em Octavio Ianni.

Atente-se ainda que no momento em tela, o regramento do campo científico e da instituição universitária estava em curso de sedimentação, e, por isso, a normatização dos procedimentos que conformam este artefato denominado "tese" não tinha vigência. A infinita variedade na quantidade de páginas, dos agradecimentos, da ausência ou presença de introdução, das formas de apresentação das notas de rodapé das maneiras de se dispor os materiais usados na tese dão prova disso. $\mathrm{Na}$ ausência de regramento das arestas, a solução dada a elas são rastros autênticos de particularidades autorais. Por isso, vale o exame: dispostas abaixo, segundo a ordenação escolhida por cada sociólogo, as categorias por meio das quais classificaram/hierarquizaram seus materiais na rubrica "bibliografia" - sugerem a imersão em modalidades distintas de trabalho, um polo teórico e outro empírico.

Maneiras de classificação dos materiais de uma tese e expressão dos padrões de intenção (teoria / empiria)

\begin{tabular}{|c|c|}
\hline $\begin{array}{l}\text { Fernando Henrique Cardoso } \\
\text { (Teoria / empiria; Geral / particular) }\end{array}$ & $\begin{array}{c}\text { Octavio Ianni } \\
\text { (Empiria; particular e geral) }\end{array}$ \\
\hline $\begin{array}{l}\text { 1. "Trabalhos teóricos sobre metodologia e sobre a } \\
\text { caracterização dos sistemas sociais globais" } \\
\text { 2. "Trabalhos de interpretação sociológica, etnológica } \\
\text { ou histórica sobre a escravidão e os negros" } \\
\text { 3. "Trabalhos sobre a formação da sociedade } \\
\text { brasileira" } \\
\text { 4. "Trabalhos gerais sobre a história política, economia } \\
\text { ou social do Rio Grande do Sul" } \\
\text { 5. "Trabalhos sobre problemas específicos da formação } \\
\text { do Rio Grande do Sul e da área platina" } \\
\text { 6. "Trabalhos específicos sobre o negro no Rio Grande } \\
\text { do Sul" } \\
\text { 7. "Memórias, notícias e viagens relativas ao Rio } \\
\text { Grande do Sul" } \\
\text { 8. "Anais, catálogos, coleções. Documentos impressos } \\
\text { e relatórios" } \\
\text { 9. "Relatórios e falas dos presidentes do Rio Grande } \\
\text { do Sul" } \\
\text { 10. "Jornais e revistas" }\end{array}$ & $\begin{array}{l}\text { 1. "Fontes primárias" } \\
\text { 2. "Obras de elaboração descritiva e } \\
\text { interpretativa sobre Curitiba, o Paraná e } \\
\text { o Brasil: históricas, econômicas, } \\
\text { sociológicas, antropológicas, etc." } \\
\text { 3. "Estudos sobre a escravatura e as } \\
\text { relações raciais entre negros e brancos" } \\
\text { 4. "Obras sobre técnicas e métodos } \\
\text { de investigação e de tratamento das } \\
\text { fontes dos dados" } \\
\text { 5. "Trabalhos sobre conceituação e } \\
\text { interpretação" } \\
\text { 6. "Dicionários" }\end{array}$ \\
\hline
\end{tabular}

Os princípios cognitivos de ordenação (classificação e hierarquização) são mais uma expressão do que foi exposto: evidenciam modalidades simetricamente opostas de defesa do marxismo, como se mostra adiante, condicionadas pelas disposições e posições destes autores. Fernando Henrique Cardoso aposta em domínio teórico raro (materialismo histórico, segundo método de leitura filosófico), conceitos extraídos de autores pouco conhecidos, ainda não canônicos nas ciências sociais, mas já crescentemente badalados (Lukács, Sartre) para

${ }^{46}$ Cf. Florestan Fernandes e Roger Bastide, Brancos e negros em São Paulo (São Paulo: Global, 2008, $4^{\text {a }}$ edição revista), cap. 1. 
desbancar outros consagrados, afronta abertamente Florestan Fernandes, lançando-se como porta-voz dos segredos e trunfos inacessíveis do "Seminário Marx". Em contrapartida, Octavio Ianni mantém-se rente aos materiais empíricos, à reconstituição histórica e apresenta um marxismo justificável por atentar para a "base econômica" da vida social (ideia corrente, não inédita e tampouco surpreendente no cenário), não disputa no mercado das competências, tampouco advoga seu monopólio de domínio autoral ou teórico. No limite, sua defesa do marxismo é menos problemática e menos arriscada que a de Fernando Henrique Cardoso.

Caracterizadas as modulações antinômicas, importa torná-las inteligíveis. Para isso, estabelece-se a seguir o nexo entre as posições ocupadas na cadeira de Sociologia I pelos dois sociólogos e suas disposições atitudinais, resultantes dos respectivos percursos sociais prévios ao ingresso na instituição.

Excerto 4. Plataforma de acordo dos sociólogos em 1952-1955: “o estado geral dessas relações na sociedade brasileira não pode ainda ser considerado conhecido. De um lado, faltam-nos dados importantes sobre o passado, dados estes que já foram parcial ou totalmente perdidos. Além disso, a situação de contacto no presente não foi investigada segundo um plano ordenado e critérios uniformes. Há trabalhos que se concentram apenas sobre um dos aspectos do fenômeno. Outros abordam o mesmo aspecto, mas com penetração de análise diversa." 47 Justificativa para a seleção da região sul: "1. (nesta área, não se desenvolveu) em grande escala, uma exploração de produtos tropicais do tipo colonial; 2. Em consequência, o regime escravocrata teve menor extensão e intensidade do que em outras áreas do país; 3. Finalmente, a colonização estrangeira (principalmente alemã, italiana e polonesa), nos moldes em que se processou, contribuiu para a elaboração de padrões de convivência racial diversos dos que prevaleceram nas zonas tradicionais. (Idem, p. XXVI). Estas especificidades levavam às questões: “... Partimos de que os padrões de interação racial que foram elaborados nas áreas da grande propriedade territorial de base escravocrata deveriam, provavelmente, encontrar condições de atualização (...) mas que deveriam sofrer reelaborações quanto à intensidade de suas manifestações, às formas de exteriorização e quanto às funções que exerciam no sistema de acomodação inter-racial. Deveríamos, pois, esclarecer em que sentido se verificou essas reelaborações e quais seus efeitos em termos da preservação dos antigos padrões de contato inter-racial no presente. Para o conhecimento desta situação no presente, julgamos conveniente elaborar uma hipótese destinada a apanhar dois aspectos inter-relacionados e igualmente importantes na análise da situação de contato: as condições de convivência racial e as ideologias raciais. (assim se poderia...) examinar as formas de exteriorização, o grau de intensidade e a natureza do 'preconceito racial' existente na sociedade brasileira." 48

Excerto 5. Do que não foi possível - "prestação de contas" com "padrões de intenção" do Seminário: "Seria possível levar um pouco mais longe a análise para mostrar que ainda não era neste nível - dos interesses da Nação, isto é, dos grupos dominantes do país - que deveríamos procurar a explicação global dos mecanismos de sustentação da escravidão como instituição e de sua validação no plano ideológico. Realmente, o ângulo mais correto e completo, a partir do qual se pode explicar a escravidão no Brasil, situa-se na discussão da formação do sistema capitalista mundial. Entretanto, seria escapar demasiadamente dos padrões relativos a uma monografia como essa, que servirá para dissertação de doutoramento, enveredar por uma análise desse tipo." 49

Excerto 6. Da necessidade da introdução: "o leitor sem interesse especial por questões desse tipo poderá sem graves prejuízos para a compreensão do trabalho, iniciar a leitura pela segunda parte da Introdução, que, como o resto do livro, refere-se a questões concretas, passíveis de serem explicadas de forma mais simples e clara." 50

Excerto 7. Do que não foi possível - "prestação de contas" com padrões de intenção da Sociologia I: "É verdade que a problemática fundamental da integração dos negros à sociedade de classes formada depois da Abolição está delineada

\footnotetext{
${ }^{47}$ Fernando Henrique Cardoso e Octavio Ianni, Cor e mobilidade social em Florianópolis (São Paulo: Editora Nacional, 1960), XXV.

48 Idem, XXXI.

${ }^{49}$ Fernando Henrique Cardoso, Capitalismo e escravidão no Brasil meridional (São Paulo: Difel, 1962), 228.

50 Idem, 10 .
} 
os capítulos finais (...). Entretanto, os resultados gerais do programa de investigações sobre o negro no Brasil Meridional só ficarão completos com a publicação posterior de trabalhos sobre a ascensão social dos negros." 51

\section{Disposições, posições, tomadas de posição}

A seleção da equipe contratada nos primeiros anos de regência de cátedra de Florestan Fernandes começou de fato, durante a pesquisa da UNESCO, acima mencionada. Ela considerou a capacidade de trabalho que os assistentes (à época, alunos e trabalhando voluntariamente) demonstraram. Os critérios de Florestan foram meticulosos na escolha dos alunos: empenho e desempenho escolares, assim como os capitais sociais disponíveis e a possibilidade de suas competências se complementarem na divisão social do trabalho interna à Sociologia I, imaginada por ele. Ele arquitetou uma equipe com papeis nitidamente diferenciados e solidários, sintonizada e coesa, estava ciente "de que suas chances de afirmação intelectual encontravam-se diretamente ligadas à ampliação de seu poder institucional"52.

Primeiro assistente, precocemente titulado mestre, responsável pelas relações institucionais da cadeira junto à reitoria, ao governo do estado e nas negociações necessárias para angariar recursos financeiros, Fernando Henrique Cardoso gradativamente torna-se o braço direito do catedrático nas operações ligadas aos poderes institucionais. Aos poucos, entre ambos estabelece-se uma nítida divisão de trabalho cujos atributos opostos e excludentes resultará no monopólio do capital temporal/institucional por Fernando Henrique Cardoso ${ }^{53}$ e no monopólio do capital intelectual/espiritual por Florestan Fernandes. Esta mútua exclusividade se sedimenta entre os anos de 1954 e 1960. Um episódio poderá ilustrar de modo cabal esta divisa.

O trabalho de política institucional delegado a Fernando Henrique Cardoso lhe custava tempo e ele sentia o sacrifício da vida intelectual aí implicado. A dimensão involuntária da confissão encontrada numa correspondência redigida de Paris para Florestan Fernandes, que, então, sozinho mantinha em operação as relações da cadeira, atesta de forma cabal o que se afirma: "Sua eficiência é de tirar o chapéu". Então o senhor entendeu como "tenho que 'dar pulos' para dar conta simultaneamente da minha carreira e da política e da administração universitária". Em seguida, afirma ser preciso "enfrentar de forma radical o problema da distribuição de tempo", razão pela qual se demitiu de todas as comissões dentro e fora da universidade antes de viajar. Ele aceita ser diretor do (então em construção) Centro de Sociologia industrial e do trabalho, desde que o não atrapalhe os "programas pessoais de desenvolvimento intelectual e de cumprimento de nossas obrigações acadêmicas”. Recomenda, por isso, equipá-lo com uma secretária, responsável pelo agenciamento e agendamento de viagens e relatórios, etc. - de modo a não sobrecarregar o futuro diretor (ele próprio) ${ }^{54}$. E continua sua negociação a respeito do tempo: "sem os compromissos da administração da universidade cumprirei meu programa pessoal mesmo dando o dobro de tempo de aulas" ${ }^{55}$.

As leituras do Seminário, em outra circunstância, poderia ser uma atividade gratuita de cultivo livre do espírito. Mas, para alguém com a história social prévia de Fernando Henrique Cardoso, sob tal regime de constrições - posição temporalmente forte e espiritualmente fraca, incitação à competição, risco de eterna subordinação ${ }^{56}$ - dificilmente. $\mathrm{O}$ investimento caracterizado acima - transporte de autores e conceitos, do seminário para a tese, concebida inicialmente sob outras diretrizes de teoria e método - corresponde a angariar exatamente o capital (espiritual) do qual é destituído. É, portanto, condicionado pela posição dominante em relação aos colegas de cadeira (que não ousariam o mesmo) e dominada em relação ao catedrático. Em contrapartida, a exclusividade de seu capital intelectual (leitura d'O Capital e de autores marxistas) invade a defesa do mesmo no interior da disciplina - como se

\footnotetext{
51 Idem, 7.

52 Heloisa Pontes, Destinos mistos. (São Paulo: Companhia das Letras, 1998), 187. Parte-se novamente, do que já foi demonstrado, para dar andamento ao argumento.

53 Pierre Bourdieu. Homo academicus (Paris: Minuit, 1984) 138-140.

${ }^{54}$ Fernando Henrique Cardoso, correspondência para Florestan Fernandes. Paris, 08/02/1962.

${ }^{55}$ Idem.

56 Wagner de Melo Romão, A experiência do Cesit (São Paulo: Humanitas, 2006).
} 
mostrou, a topografia teórica é a hierarquia objetiva invertida - orientando a classificação dos pares, particularmente de seu professor, a quem interdita possibilidades combinatórias das matrizes teóricas (o que não seria marxista). Sua estratégia discursiva é a manifestação par excellence da homologia entre as estruturas objetivas das instituições de saber e os esquemas cognitivos dos agentes ${ }^{57}$.

Segundo assistente, sem a sobrecarga dos papéis políticos e das negociações acumuladas juntamente com as tarefas docentes, por Fernando Henrique Cardoso, sem ter participado da pesquisa da UNESCO, pois havia interrompido sua graduação no momento de seu matrimônio, sem ter ainda mestrado, quando a equipe é montada, Octavio Ianni encontrase em posição que insta menos à disputa, tanto na Sociologia I quanto no Seminário. Embora esteja imerso no espaço de questões e problemas desses dois pólos e opere no interior do repertório teórico e temático de ambos, tudo se passa como se não participasse da disputa em nenhum deles. Enquanto a divisa de capitais exclusivos, excludentes e interdependentes entre Florestan Fernandes (espiritual) e Fernando Henrique Cardoso (temporal) atiça a concorrência no vetor mais fraco e aguça a defesa do pólo mais forte, a posição de Ianni, inferior a ambos, libera-o do confronto. Porém, não de algumas responsabilidades. Duas modificações que o sociólogo realiza no texto de sua tese para publicação em livro corroboram esse relativo desprendimento da disputa e da configuração do Seminário, mas documentam o quanto a autoridade desse experimento de leitura vai se sedimentando por meio das defesas de tese. $\mathrm{O}$ texto programático escrito por Giannotti está ausente de bibliografia da tese de Ianni, mas é introduzido em livro, na listagem das obras. (Cf. imagens no final).

Fernando Henrique Cardoso e Octavio Ianni não eram primeiro e segundo assistentes por acaso. As posições institucionais refratavam seus percursos sociais originários diametralmente opostos. Como as afinidades eletivas das origens sociais não são indiferentes enquanto acicates da disputa de um e do comedimento de outro em relação ao professor, é preciso atentar à história social prévia ao encontro dos três sociólogos.

Octavio Ianni nasceu em Itu, em 1926, numa família modesta de imigrantes do sul da Itália. Tendo cursado regularmente a faculdade em 1949 e 1950, nos dois anos seguintes interrompe a graduação; casa-se, trabalha como assistente de editora na Companhia Editora Nacional, e como tipógrafo em Osasco. Ele foi jocosamente apelidado de "italianinho de Itu". Retomando a graduação, seu colega de turma ingressante no curso de Ciências Sociais, Fernando Henrique Cardoso, já professor, dá-lhe aulas ${ }^{58}$. À desvantagem social somou-se a etária, ou, talvez, nesta se manifestasse aquela: era cinco anos mais velho que Fernando Henrique Cardoso e angariava os títulos num gap temporal, comprometendo algo da "mágica" do "gênio precoce", tão valorizado no caso de seu colega e na cultural escolar em geral.

Filho de uma imigrante portuguesa e de pai desconhecido, Florestan Fernandes nasceu em 1920 em São Paulo e conheceu toda sorte de dificuldades para sobreviver. Teve uma trajetória escolar entrecortada pela necessidade material e concluiu os estudos no antigo curso madureza. Padeceu da solidão e do desamparo dos que não têm família nem amigos, acompanhando a lenta plebeização que vingaria na FFCL-USP, onde cursou Ciências Sociais, no início dos anos 1940. Compensou suas desvantagens sociais de origem dando provas de empenho e dedicação aos estudos, reconhecidos por Roger Bastide que lhe reservou a regência da cátedra. Não surpreende que Florestan reconheça a si próprio em Ianni. O retrato que faz do ex-aluno é parcialmente seu: tinha no "ar sério, tranquilo, ensimesmado, modesto e retraído, desconfiado", levara para a "faculdade contas a saldar com aquele mundo estranho"; era "desajeitado" em meio às "pessoas que ostentavam certa superioridade"

Fernando Henrique Cardoso nasceu em 1931, no Rio de Janeiro. Primogênito em uma família de militares, qualquer genealogia dedicada a ele "atesta os indicadores de alta origem social e a participação direta de seus ascendentes nos eventos mais relevantes da

\footnotetext{
${ }_{57}$ Pierre Bourdieu. La noblesse d'État: grandes écoles et esprit de corps (Paris, Minuit, 1989) 46-47.

${ }^{58}$ Fernando Henrique Cardoso, Entrevista, 2006, 70.

${ }^{59}$ Florestan Fernandes. "O encanto da vida", em Humanismo e compromisso, ed. Regina Crespo (São Paulo: Unesp, 1996), 11.
} 
história do Brasil contemporâneo"60. Ele cresceu em meio a crônicas familiares grandiosas, incutindo-lhe a convicção de que ele e os seus eram personagens em histórias nas quais a maioria das pessoas vê longínquos heróis. Cursou o primário e o ginásio entre o Rio de Janeiro e São Paulo, em função de deslocamentos do pai, teve professora particular de francês, algo relativamente comum à época entre famílias abastadas. Cursou o colegial no Colégio São Paulo. Em 1949, prestou dois vestibulares, sendo reprovado em um - o latim da Faculdade de Direito; e aprovado em outro, o de Ciências Sociais para a FFCL-USP. Aluno exemplar da Faculdade, antes de concluí-la, precisou da autorização do reitor dada sua pouca idade para tanto, tornou-se professor assistente na Faculdade de Ciências Econômicas e Administrativas (FCEA-USP), responsável por ensinar História Econômica da Europa. O papel de azeitamento das relações políticas institucionais, a ele delegado por Florestan Fernandes - cuja posição institucionalmente superior não apagava a distância de origem entre ambos - era compatível com o aprendizado doméstico da socialização política. É ele mesmo quem afirma: "meu pai era político. Está no meu sangue" ${ }^{61}$.

A FFCL-USP viabilizava a saga da ascensão social nos casos de Florestan Fernandes e de Octavio Ianni, mas estava longe de ser satisfatória para Fernando Henrique Cardoso. As curvas sociais - ascenso e declínio - marcaram os investimentos dos três e as distâncias e afinidades de origem condicionaram disposições para o confronto aberto e para a solidariedade mútua. A audácia de Fernando Henrique Cardoso e o comedimento de Octavio Ianni face ao poder de Florestan Fernandes ganham pleno sentido à luz dessas relações.

\section{Considerações Finais}

Ao discutir a explicação histórica dos quadros, Michael Baxandall faz uma observação simples e precisa. Diferentemente dos documentos históricos produzidos por outras atividades, os artefatos simbólicos e científicos são intencionais, ou seja: eles são a solução de um problema formulado por seu produtor (seja ele, pintor, cientista, arquiteto). Por isso, entender o trabalho deste produtor pressupõe compreender como elaborou tal problema e quais circunstâncias particulares o levaram tanto a propô-lo quanto resolvê-lo: "explicar uma intenção não é contar o que se passou na cabeça do pintor (ou engenheiro, ou cientista), mas elaborar uma análise sobre seus fins e seus meios" - no caso dos cientistas sociais: os autores que dispõem, os conceitos, os materiais, o tempo ${ }^{62}$. Este foi esforço do presente trabalho ao caracterizar as condições que favoreceram a elaboração de problemas e instaram soluções criativas face ao sistema de "padrões de intenção" aos quais os seminaristas submeteram uns aos outros.

Procurou-se colocar a serviço desse enquadramento analítico - a intenção entendida como o nexo entre o projeto de um artefato (tese / defesa do marxismo), os problemas e os recursos para realizá-lo - as noções de campo e habitus. Daí a recuperação da história social prévia dos três sociólogos, substrato do "sistema de disposições" em operação nas posições ocupadas e nas tomadas de posição - uns em relação aos outros. No coração das condutas divergentes encontra-se a disposição para o risco - de Fernando Henrique Cardoso e a indisposição para ele, por parte de Florestan Fernandes (na montagem da cadeira) e de Ianni (na elaboração da tese, mantendo-se rente e obediente aos ensinamentos do catedrático). O talento para tanto e a coragem de investir em empreendimentos de risco não são recursos distribuídos socialmente de modo equitativo. Como assinalou Pierre Bourdieu, a propensão para assumir riscos se liga às margens de uma incerteza de ganhos simbólicos dentro da qual os agentes ungidos de segurança material e encorajados por reforço e apoio sociais sabem jogar ${ }^{63}$. Era o caso de Fernando Henrique Cardoso, por sua trajetória social e escolar prévia, pelo apoio de seus amigos seminaristas, por tudo que seu passado anunciava de futuro. Com efeito, se "as disposições (as preferências, os gostos) só podem se constituir em meio à relação com as

\footnotetext{
${ }^{60}$ Afranio-Raul Garcia Jr. "A dependência da política”, em Democracia, crise e reforma, Ed. Maria d'Incao (São Paulo: Paz e Terra, 2010), 96.

${ }^{61}$ Brigitte Leoni. Fernando Henrique Cardoso, o Brasil do possivel (Rio de Janeiro: Nova Fronteira, 1997), 44.

62 Michael Baxandall. Padrões de intenção. A explicação histórica dos quadros (São Paulo: Companhia das Letras, 2006), 162.

${ }_{63}$ Pierre Bourdieu. Homo Academicus, 144.
} 
tendências imanentes de um universo social" lidando "com as probabilidades inscritas em suas regularidades" ${ }^{64}$ - estas, por sua vez, deveriam ser reconstituídas pela recuperação do campo.

As controvérsias suscitadas por este conceito e as particularidades dos "intelectuais à brasileira" " ${ }^{65}$, cuja dependência da política impede que se fale em campo no sentido rigoroso do termo - requerem procedimentos mais cuidadosos em seu uso. Por outro lado, o reconhecimento de um sistema de relações hierárquicas estruturado impôs que se operasse com a noção de espaço de posições - implícita em "campo" - em detrimento da discussão a respeito da "autonomia" ${ }^{66}$. Aposta-se que a recuperação deste sistema de relações no interior do qual os agentes são instados a agir intelectualmente seja imprescindível para tornar inteligíveis suas obras.

Este escopo teórico tem sido voltado para o exame de numerosas manifestações artísticas e intelectuais, como assinala a recepção, no Brasil, da obra de Pierre Bourdieu ${ }^{67}$. E, no entanto, embora a história do marxismo ofereça um universo inesgotável de criações que requereriam esta abordagem, infelizmente, ela ainda patina, como observou Horacio Tarcus, num tipo de debate que recorre ao uso irônico das aspas, sugerindo que tal ou tal autor é mais ou menos, verdadeiramente ou não "marxista" 68 . O problema já foi notado por marxistas ilustres. Se for verdade que uma introdução cristaliza - pelo que afirma e pelo que deixa de afirmar - os problemas mais agudos do trabalho que apresenta, é instigante meditar a respeito do que Eric Hobsbawm afirma, ao abrir sua alentada coletânea da história do marxismo: ela "não pode ser apenas a história do que os marxistas, e Marx, em primeiro lugar, pensaram, escreveram e discutiram, uma história que se explicite na tradicional reconstrução da árvore genealógica das ideias, ou através do método marxista de análise da relação entre "consciência" e o "ser social" ". Não fosse a tendência de se deixarem levar pela genealogia das ideias, por que advertir os marxistas? Ora, neste filão bastante diversificado, tão difícil de delimitar quanto mais fácil seja de identificar - "estudos ligados a Marx e marxismo" - por vezes, adota-se procedimentos que traem a pretensa filiação que pretendem estabelecer ao tomá-lo por objeto, produzindo trabalhos nos quais a desconsideração da sócio-lógica (grupos de estudo, universidade, partidos, tendências partidárias, sindicatos, movimentos sociais ) dos usos e das leituras da obra de Karl Marx suscita falsos problemas. O historiador intuía, ou já havia enfrentado na organização dos volumes, o problema a respeito do qual está advertindo seus pares e para o qual este trabalho ambiciona oferecer uma alternativa. Ao adotar a perspectiva da sociologia da cultura, foi possível recusar uma definição prévia, normativa, interessada/acusatória ou essencialista de "marxismo" e de "marxista" 70_ sempre pressuposta naquelas aspas em que se aprazem comentadores. A abordagem adotada, por exigir a reconstituição do princípio que anima a dinâmica relacional e conflitiva em torno da própria delimitação das fronteiras sociais, intelectuais e políticas em jogo na definição do termo, oferta uma saída àquelas definições sem a desconsideração delas. Por isso, os agentes foram tratados como leitores e seminaristas de Marx.

64 Pierre Bourdieu, Meditaçoes pascalianas (Rio de Janeiro: Bertrand, 2001), 262.

${ }^{65}$ Sergio Miceli, Intelectuais à brasileira (São Paulo: Companhia das Letras, 2001).

66 Adoto a mesma saída para o problema do conceito de campo, isto é - em detrimento da análise da "autonomia", a manutenção da ideia de "espaço" - encontrada em Gisèle Sapiro. "Le champ est-il national?" em Actes de la Recherche en Sciences Sociales, 200, 2013.

${ }^{67}$ Fernando Pinheiro Filho, "The renovation: aspects of Pierre Bourdieu's reception in Brazil" em Sociologica (Bologna), 1, 2009. Entrementes, é válido insistir que a despeito do crescente volume de citações e traduções, os procedimentos requeridos pela análise de feitio bourdiesiana permanecem estrangeiros. É comum o queixume vulgar dos que, ignorando-os, consideram-nos a serviço de uma história de intrigas. Um dos objetivos desta análise, centrando-se no nexo entre disposições prévias, posições objetivas e tomadas de posição no espaço da concorrência e colaboração foi tentar demonstrar que o que os leitores mal informados consideram "intrigas" são elementos da construção da determinação sociológica. Em defesa dos procedimentos coerentes com a adoção desta teoria, sublinhe-se ainda que não se tratam dos indivíduos empíricos tal como dados na realidade, mas tal como construídos pela teoria do mundo social de Pierre Bourdieu - advertência que o próprio elabora no capítulo 1, de seu Homo academicus.

${ }^{68}$ Horacio Tarcus, Marx na Argentina, 2007, 25-27.

${ }^{69}$ Eric Hobsbawm. "Introdução" em História do marxismo, v. I. (Rio de Janeiro: Paz e Terra, 1983), 12.

70 Ofereço, a título ilustrativo, um dos exemplos mais conspícuos nesta matéria, para o caso brasileiro. Um historiador das ideias marxistas afirma, referindo-se a um comunista: "o doutrinarismo cacete do recém-convertido Brandão (...) tropeça em ideias preconcebidas, que desprezam toda e qualquer mediação e se encerram em enunciações surpreendentemente simplistas" Leandro Konder, $A$ derrota da dialética (São Paulo: Expressão Popular, 2009), 185. 
(1)

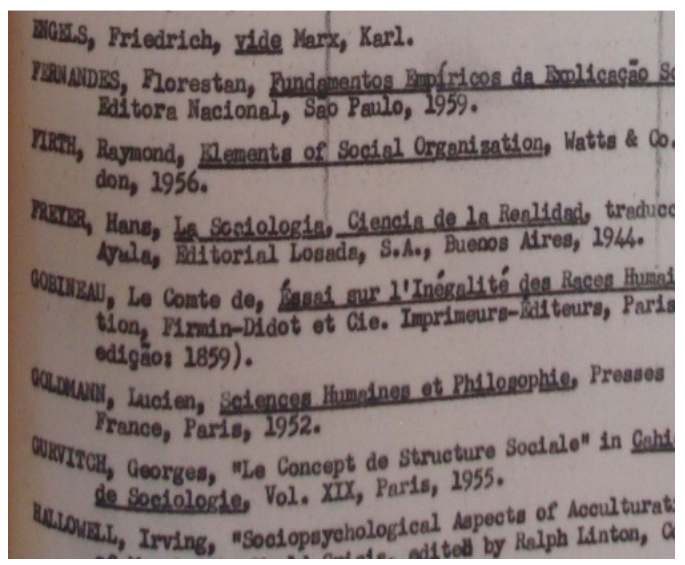

ENGELS, Friedrich, vide Marx, Karl.

FERNANDES, Florestan, Fundamentos Empiricos da Explicacio Sociológica, Companhia Editôra Nacional, São Paulo, 1959.

FIRTH, Raymond, Elements of Social Orgunization, Watts \& Co, Second edition, London, 1956.

FREYER, Hans, La Sociologia, Ciencia de la Realidad, traducción por Francisco Ayala, Editorial Losada, S. A., Buenos Aires, 1944.

GIANNOTTI, J. Arthur, "Notas para uma análise Metodológica de 0 Capital", Revista Brasiliense, № 29, São Paulo, 1960.

GOLDMANN, Lucien, Sciences Humaines et Philosophie, Presses Universitaires de France, Paris, 1952.

GURVITCH, Georges, "Le Concept de Structure Sociale" in Cahiers Internationaux de Sociologie, Vol. XIX, Paris, 1955.

Giannotti - seminário ausente e presente. ${ }^{71}$

(2)

1. Bibliografia da tese de Octavio Ianni. O negro na sociedade de castas. O regime servil numa comunidade do Brasil meridional. (Tese de doutoramento, FFCL-USP, 1961). 2. Bibliografia do livro As metamorfoses do escravo. (São Paulo: Difel, 1962).

\footnotetext{
${ }^{71}$ Obviamente, a inferência realizada conta mais indicadores além da introdução de um texto "esquecido" na bibliografia da tese e "lembrado" na bibliografia em livro. A introdução deste item, ao que tudo indica (cf. Lidiane S. Rodrigues. A produção social do marxismo, 2013) resulta do impacto das arguições das teses dos sociólogos Fernando Henrique Cardoso e Octavio Ianni.
} 